\title{
A non-pediocin low molecular weight antimicrobial peptide produced by Pediococcus pentosaceus strain IE-3 shows increased activity under reducing environment
}

\author{
Pradip K Singh, Shalley Sharma, Annu Kumari and Suresh Korpole*
}

\begin{abstract}
Background: Species of the genus Pediococcus are known to produce antimicrobial peptides such as pediocin-like bacteriocins that contain YGNGVXC as a conserved motif at their N-terminus. Until now, the molecular weight of various bacteriocins produced by different strains of the genus Pediococcus have been found to vary between 2.7 to $4.6 \mathrm{kD}$. In the present study, we characterized an antimicrobial peptide produced by P. pentosaceus strain IE-3.

Results: Antimicrobial peptide was isolated and purified from the supernatant of $P$. pentosaceus strain IE- 3 grown for $48 \mathrm{~h}$ using cation exchange chromatography and reversed-phase high-performance liquid chromatography (RP-HPLC) techniques. While MALDI-TOF MS experiments determined the precise molecular mass of the peptide to be $1701.00 \mathrm{Da}$, the de novo sequence (APVPFSCTRGCLTHLV) of the peptide revealed no similarity with reported pediocins and did not contain the YGNGVXC conserved motif. Unlike pediocin-like bacteriocins, the low molecular weight peptide (LMW) showed resistance to different proteases. Moreover, peptide treated with reducing agent like dithiothreitol (DTT) exhibited increased activity against both Gram-positive and Gram-negative test strains in comparison to native peptide. However, peptide treated with oxidizing agent such as hydrogen peroxide $\left(\mathrm{H}_{2} \mathrm{O}_{2}\right)$ did not show any antimicrobial activity.

Conclusion: To our knowledge this is the lowest molecular weight peptide produced by members of the genus Pediococcus. The low molecular weight peptide shared amino acid arrangement with $\mathrm{N}$-terminal sequence of Class $\|$ a, pediocin-like bacteriocins and showed increased activity under reducing conditions. Antimicrobial peptides active under reduced conditions are valuable for the preservation of processed foods like meat, dairy and canned foods where low redox potential prevails.
\end{abstract}

Keywords: Pediococcus, LMW antimicrobial peptide, MALDI-TOF MS, DTT effect

\section{Background}

Bacteria produces different kinds of antimicrobial substances including ribosomally synthesized bacteriocins and non-ribosomally synthesized antibiotics or lipopeptides as a part of their defense strategies in complex environments such as fermented foods and the human gut. Members belonging to the lactic acid bacteria (LAB) family with ability to produce bacteriocins are frequently found in these environments [1]. LAB strains are

\footnotetext{
* Correspondence: suresh@imtech.res.in

MTCC and Gene Bank, CSIR-Institute of Microbial Technology, Sector 39A, Chandigarh, 160036, India
}

recognized as GRAS (Generally Regarded As Safe) microorganisms and have been studied in detail for biotechnological applications together with the bacteriocins produced by these strains [2,3]. Members of the genus Pediococcus are classified within the LAB family and are reported to produce bacteriocins without post-translational modifications that are classified under class II bacteriocins $[4,5]$. The bacteriocins classified under class IIa are called as pediocin-like bacteriocins because the first antimicrobial peptide of this class (pediocin PA-1) was isolated from Pediococcus sp. [6]. They include variable size peptides ranging from 2.7 to $4.6 \mathrm{kDa}$ [7-9] with high sequence 
homology, disulfide bonds and a conserved motif YGNGVXC in their N-terminal domain [10]. However, bacteriocins lacking the consensus motif are also classified under pediocin-like bacteriocins [2]. Initially pediocin-like bacteriocins were reported to be produced by members of the genus Pediococcus [10] but later were also isolated from members of other genera like Lactobacillus, Enterococcus and Bacillus [11-14]. Since pediocin-like bacteriocins are well-known to inhibit the growth of food spoilage and pathogenic bacteria Listeria monocytogenes, they are also termed as anti-listerial bacteriocins and considered as potential antimicrobial additives for food preservation. Though pediocin producing members of the genus Pediococcus are largely isolated from dairy products, they have also been reported from diverse environments including human stool sample $[15,16]$. However, pediocin-like bacteriocins produced by different isolates exhibited 40-60\% similarity in their amino acid sequence [10]. Among the known variants of pediocin-like bacteriocins, pediocin PA1 is well-studied $4.6 \mathrm{kDa}$ antimicrobial peptide with thermo-stability and wide $\mathrm{pH}$ range activity [17]. Nevertheless, it was inactivated by proteases like pepsin, trypsin, chymotrypsin, proteinase $\mathrm{K}$ and pronase $\mathrm{E}$ [10]. Further, structure of the pediocin PA-1 revealed presence of two $\beta$-strands connected by a $\beta$-hairpin made up of five amino acid residues in their $\mathrm{N}$-terminal sequence that play an important role in antimicrobial activity [18-20]. In this study, we describe the isolation, purification and characterization of a novel antimicrobial peptide produced by $P$. pentosaceus strain IE-3 isolated from a dairy effluent sample [21].

\section{Results and discussion}

\section{Growth conditions and antibacterial activity assay}

$P$. pentosaceus strain IE-3 showed very little growth while grown in aerobic conditions and optimal growth was observed under anaerobic conditions. The $48 \mathrm{~h}$ cell free fermented broth (CFB) of $P$. pentosaceus strain IE-3 grown in anaerobic broth displayed antimicrobial activity against different indicator strains in well diffusion assay (Table 1). In contrast to typical narrow spectrum activity shown by pediocin-like bacteriocins [10], the antimicrobial peptide produced by strain IE-3 inhibited growth of Gram-positive and Gram-negative indicator strains. The most sensitive strain among the test strains was Micrococcus luteus that showed a $26 \mathrm{~mm}$ zone of inhibition. There was no activity observed against other strains of Pediococcus, yeasts and fungi. A curve displaying antimicrobial production versus bacterial growth showed that the antimicrobial peptide production was initiated during early $\log$ phase ( $6 \mathrm{~h}$ of incubation) which increased to a maximum level by initial stationary phase $(14 \mathrm{~h})$ and remained constant thereafter (Figure 1a). Antimicrobial activity was obtained when the $P$. pentosaceus strain IE-3
Table 1 Antimicrobial activity of the cell free fermented broth (CFB) of $\mathbf{4 8} \mathrm{h}$ grown culture against various test strains (mean values of triplicate experiments)

\begin{tabular}{|c|c|}
\hline Test strain & $\begin{array}{l}\text { Inhibition zone } \\
\text { using CFB }(\mathrm{mm})\end{array}$ \\
\hline \multicolumn{2}{|l|}{ Gram-positive } \\
\hline Listeria monocytogenes (MTCC 839) & 13 \\
\hline Lactobacillus plantarum (MTCC 2621) & 10 \\
\hline Clostridium bifermentas (MTCC 11273) & 10 \\
\hline Clostridium sordelli (MTCC 11072) & 12 \\
\hline Bacillus subtilis (MTCC 121) & $<10$ \\
\hline Staphylococcus aureus (MTCC 1430) & 10 \\
\hline Micrococcus luteus (MTCC 106) & 26 \\
\hline Pediococcus acidilactici (MTCC 7442) & - \\
\hline P. pentosaceus (MTCC 9484) & - \\
\hline P. pentosaceus (MTCC 10308) & - \\
\hline \multicolumn{2}{|l|}{ Gram-negative } \\
\hline Vibrio cholera (MTCC 3904) & 15 \\
\hline Escherichia coli (MTCC 1610) & $<10$ \\
\hline Pseudomonas aeruginosa (MTCC 1934) & 10 \\
\hline Serratia marcescens (MTCC 97) & - \\
\hline \multicolumn{2}{|l|}{ Fungi } \\
\hline Candida albicans (MTCC 183) & - \\
\hline Asperigillus flavus (MTCC 8188) & - \\
\hline
\end{tabular}

was grown in different media including minimal medium with optimal production obtained in media like anaerobic broth, MRS and reinforced clostridial broth, the latter containing reducing agents (Figure $1 \mathrm{~b}$ ). Significant delay was observed to reach exponential growth phase by strain IE-3 while growing in minimal media that resulted in slow antimicrobial production (data not shown).

\section{Purification of antimicrobial peptide}

The crude extract obtained by Diaion HP20 chromatography showed significant increase in antimicrobial activity compared to CFB. Gel electrophoresis analysis of this extract displayed a peptide band between 1.7 and $4.5 \mathrm{kDa}$ on tricine SDS-PAGE that showed antimicrobial activity against $L$. monocytogenes in in-gel activity assay (Figure 2a). Direct detection of antimicrobial activity by in-gel activity assay revealed that the inhibition was caused by a low molecular weight (LMW) peptide. The extract was purified on a cation exchange column and the active fraction obtained was used for gel filtration chromatography analysis that anticipated the molecular mass to be in the range of $2.0-5.5 \mathrm{kDa}$ (Figure 2b). The purified peptide showed a single peak in reversed phase HPLC with absorbance between 260$280 \mathrm{~nm}$ (Figure 2c) that may be due to the presence of 


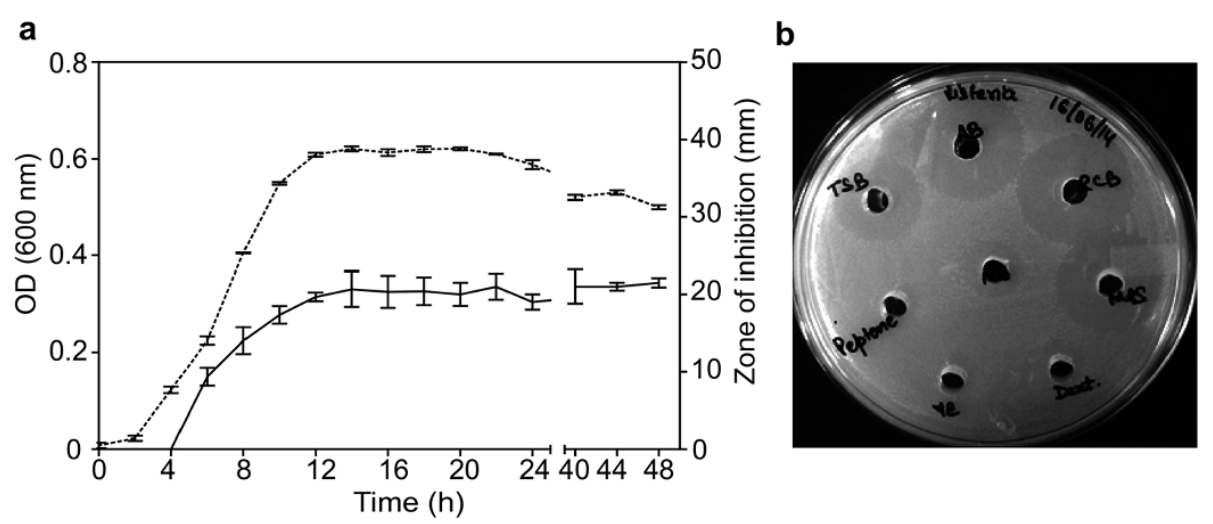

Figure 1 Antimicrobial production by $P$. pentosaceus strain IE-3. (a) Correlation between antimicrobial peptide production and growth of strain IE-3. Growth measured as OD at $600 \mathrm{~nm}$ (dotted lines), bacteriocin production as zone of inhibition (continuous line). Error bars shows \pm SD for triplicate experiments. Culture was grown in anaerobic broth under anaerobic conditions at $30^{\circ} \mathrm{C}$ on a shaker incubator. (b) Antimicrobial assay of $24 \mathrm{~h}$ cell free fermented broth obtained by growing strain IE-3 on different media.

a

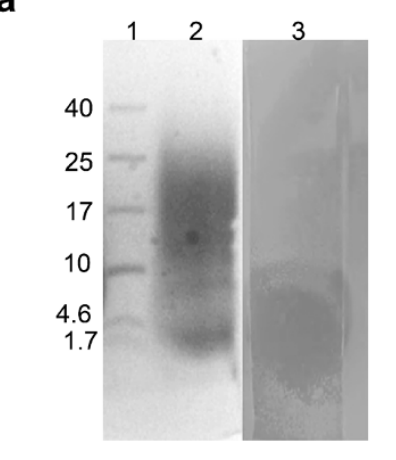

b

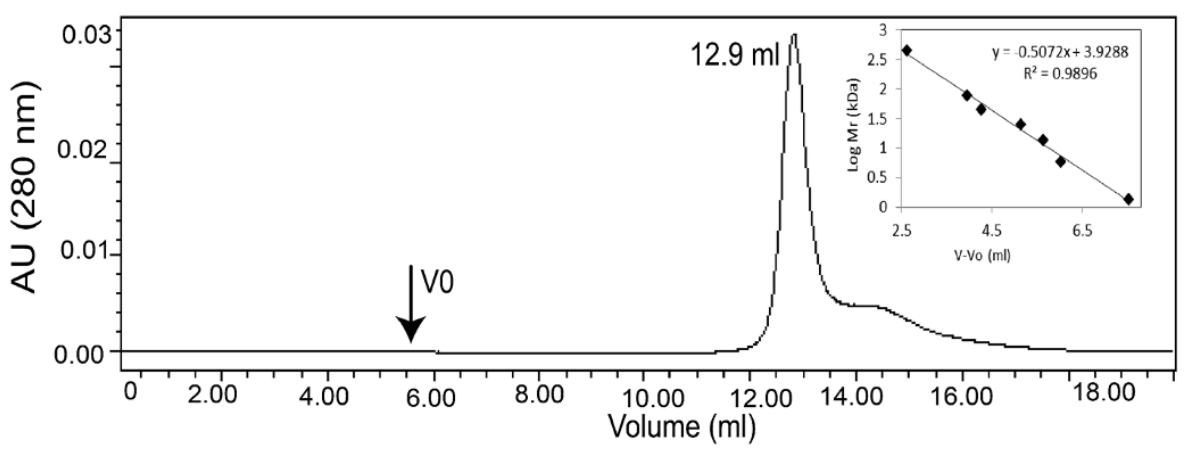

C

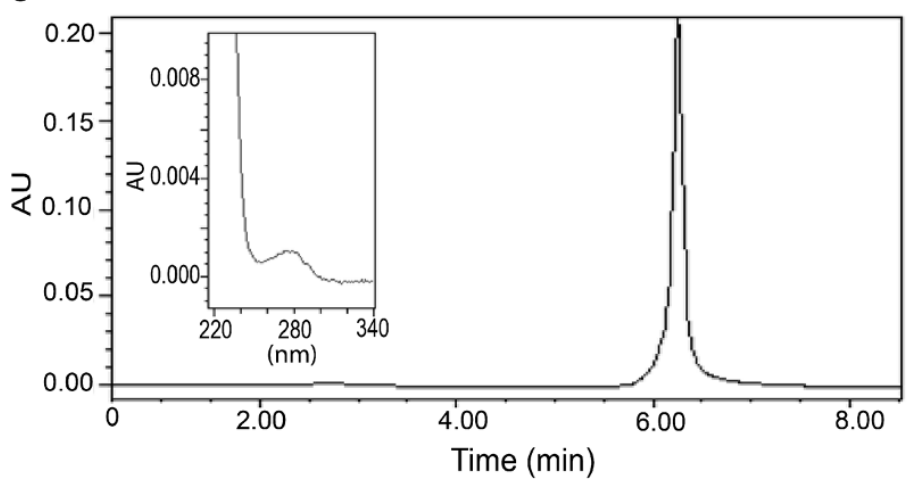

d

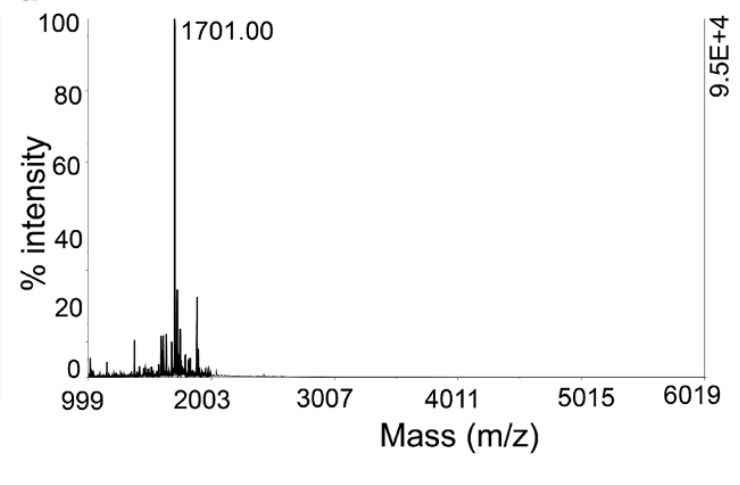

Figure $\mathbf{2}$ Characterization of low molecular weight antimicrobial peptide produced by $P$. pentosaceus strain IE-3. (a) In-gel activity assay of crude extract on 18\% tricine SDS-PAGE gel, lane 1 contains low molecular weight protein marker, lane 2 crude extract obtained from Diaion HP20 and lane 3 showing antimicrobial activity against L. monocytogenes MTCC 839 (b) Size determination by gel filtration chromatography of cation exchange purified peptide along with standard graph (of known molecular weight proteins depicts low molecular size). (c) Reverse-phase HPLC profile of purified antimicrobial peptide and inset showing the absorbance between 260-280 nm. (d) Intact molecular mass showing as 1701.00 Da in MALDI-TOF analysis. 
aromatic amino acids like phenylalanine. During storage of the purified peptide at room temperature significant reduction in antimicrobial activity was observed within $24 \mathrm{~h}$, but was stable when stored at $-20^{\circ} \mathrm{C}$. Subsequently, it was found that the loss of antimicrobial activity was due to oxidation of peptide as observed for pediocin-like bacteriocins [22].

\section{Molecular mass analysis and de novo sequencing of LMW peptide}

The molecular mass for LMW antimicrobial peptide was determined as $1701.00 \mathrm{Da}$ (Figure 2d) by MALDI-TOF MS. The primary structure of the peptide by MS/MS sequencing revealed the sequence as APVPFSCTRGCLTHLV with high score value of 47.59 (Figure 3). The mass obtained in MALDI-TOF is in agreement with the estimated theoretical average mass (1701.03 Da) obtained for the sequence. Minor differences in mass may be due to the instrument error which deviates up to $50 \mathrm{ppm}$. Further, bioinformatics analysis of the sequence did not show any significant similarity with known pediocin-like bacteriocins or other bacterial AMPs available with databases like Bactibase [23,24] or Collection of Antimicrobial Peptide (CAMP) database [25]. In fact, the de novo sequence was used for blast analysis against the published genome of strain IE-3, but could not find any significant blast hit covering the entire peptide sequence in the annotated proteins. Further, genome sequence analysis to find the ORF coding this peptide did not show any significant similarity. In this regard, it is pertinent to note that the genome of IE-3 is a draft version, hence, putative region encoding the small peptide may have missed in the draft genome due to gaps formed during the assembly of raw sequence data (as contig cutoff size of $\geq 500$ nucleotides was used). Considering ambiguities in de novo sequencing, search was also made by replacing Leu residue with Ile as well as other de novo sequences obtained with low score values, however, no ORF was found in genome sequence. As no ORF detected in genome, it is anticipated that antimicrobial peptide might be produced from medium components by the strain IE-3. Nevertheless, synthesis of peptide from the medium components is ruled out as the peptide production was observed in minimal medium containing an inorganic nitrogen source. Though the de novo sequence similarity search using APD2 [26] revealed low similarity (37\% similarity) with the eukaryotic antimicrobial peptide, temporin LTb, it did not show any conserved motifs observed for temporins [27]. Antimicrobial peptide prediction analysis [26] of the de novo sequence suggested that the peptide could be a potential antimicrobial peptide

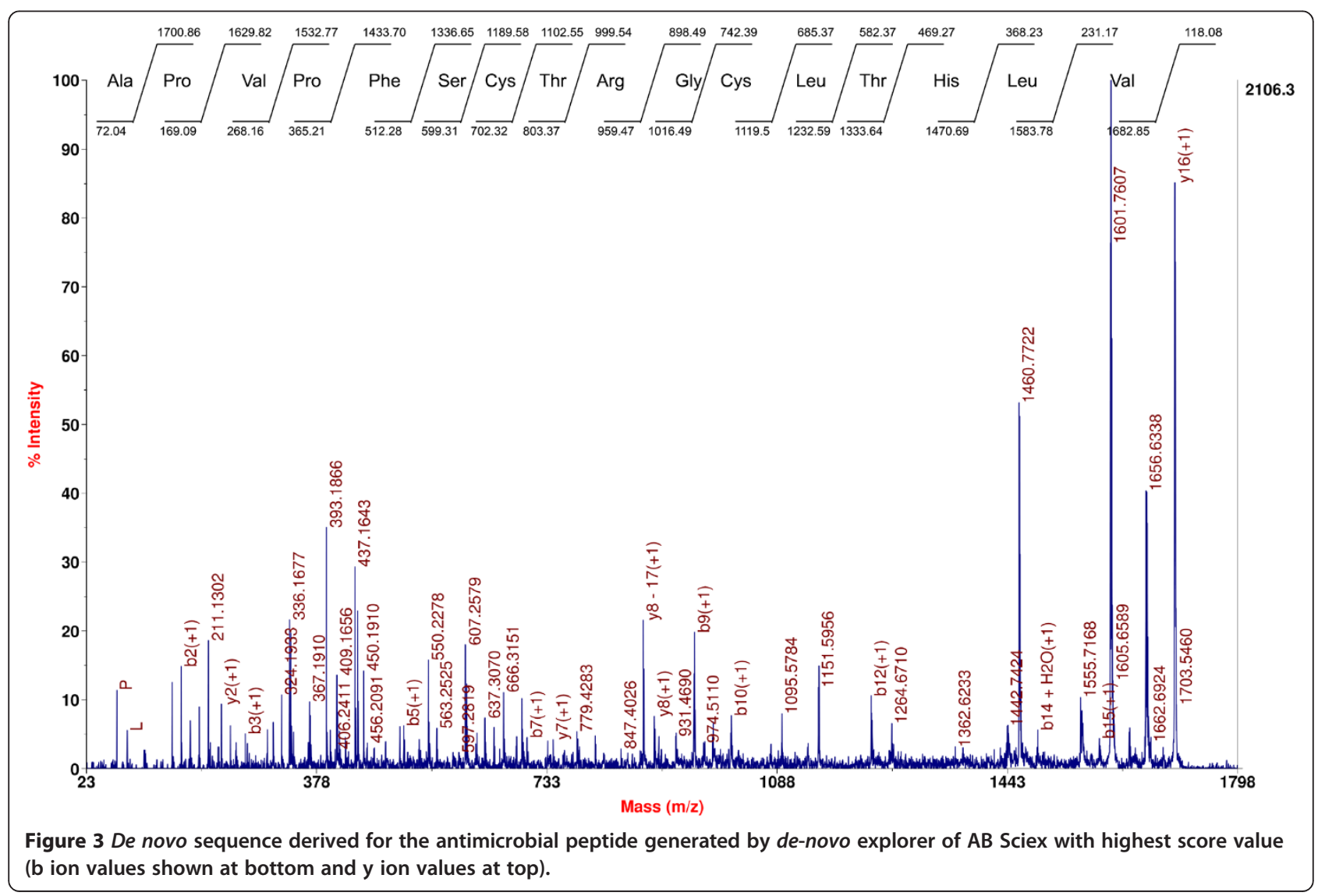


with the presence of cationic, aromatic and hydrophobic amino acids, along with two cysteine residues. Moreover, this LMW peptide shares an amino acid arrangement with $\mathrm{N}$-terminal sequence of other pediocin-like bacteriocins such as pediocin PA-1 $[9,28]$. Remarkably, the five amino acids (CTRGC) of the peptide showed amino acids pattern similarity with $\beta$-hairpin composition (CTKSGC) of pediocin-like bacteriocins [29] where the positively charged amino acid play crucial role in antimicrobial activity [10]. In fact, addition of a positively charged amino acid within this patch showed significant increase in antimicrobial activity of pediocin PA-1 [30]. Additionally, structure prediction analysis for the LMW peptide showed antiparallel $\beta$-sheet confirmation (Figure 4 ) where hydrophobic and positively charged amino acids are enclosed by two cysteine residues (Cyt7-Cyt11).

Effect of $\mathrm{pH}$, temperature, proteolytic enzymes, reducing agent and $\mathrm{H}_{2} \mathrm{O}_{2}$ on antimicrobial activity

The LMW antimicrobial peptide was found to be thermo-stable as there was no reduction observed in its antimicrobial activity even after $30 \mathrm{~min}$ of incubation at $100^{\circ} \mathrm{C}$. However, it displayed sensitivity towards the $\mathrm{pH}$ as the maximum activity was observed at $\mathrm{pH} 5$ and significant loss was found at $\mathrm{pH} 8$ and above (Table 2). Unlike pediocin-like bacteriocins, the low molecular weight peptide in this study was found to be resistant to proteolytic cleavage as an antimicrobial assay performed upon incubation with proteolytic enzymes showed no reduction in activity. Stable activity upon treatment with amylase revealed the absence of any sugar moiety associated with inhibition activity of the bacteriocin. Interestingly, the peptide showed significant increase in antimicrobial activity when it was tested upon incubation with DTT (Figure 5a). The increase in activity was observed with the increase in DTT concentration up to $150 \mathrm{mM}$ (Table 2). However, peptide incubated with $\mathrm{H}_{2} \mathrm{O}_{2}$ did not show any antimicrobial activity confirming the inactivation of LMW peptide upon oxidation. Results of

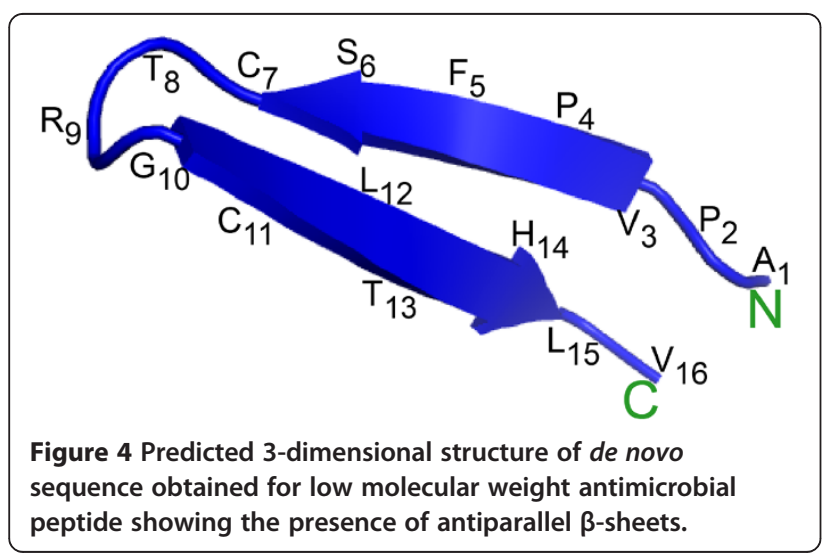

Table 2 Influence of different pH values and DTT concentrations on antimicrobial activity of the LMW peptide produced by $P$. pentosaceus strain IE-3

\begin{tabular}{lll}
\hline Treatments & Reaction condition & Residual activity (\%) \\
\hline $\mathbf{p H}$ & & \\
2 & Overnight/ RT & 100.0 \\
3 & Overnight/ RT & 100.0 \\
4 & Overnight/ RT & 100.0 \\
5 & Overnight/ RT & 100.0 \\
6 & Overnight/ RT & 87.5 \\
7 & Overnight/ RT & 75.0 \\
8 & Overnight/ RT & 37.5 \\
9 & Overnight/ RT & 25.0 \\
10 & Overnight/ RT & 12.5 \\
DTT concentration & & \\
$0 \mathrm{mM}$ & $1 \mathrm{~h} / \mathrm{RT}$ & 100.0 \\
$50 \mathrm{mM}$ & $1 \mathrm{~h} / \mathrm{RT}$ & 125.0 \\
$100 \mathrm{mM}$ & $1 \mathrm{~h} / \mathrm{RT}$ & 143.7 \\
$150 \mathrm{mM}$ & $1 \mathrm{~h} / \mathrm{RT}$ & 143.7 \\
\hline
\end{tabular}

RT, room temperature.

control DTT experiments showed no effect on the growth of indicator strains.

\section{Determination of minimum inhibitory concentration of the LMW peptide}

Determination of minimum inhibitory concentration (MIC) for various indicator organisms revealed that the peptide was most active against $M$. luteus of Gram-positive strains with an MIC value of $6.3 \mu \mathrm{M}$. Among the Gram-negative strains, $V$. cholera growth was inhibited at $25.4 \mu \mathrm{M}$ concentration. The MIC values observed for the peptide were higher when compared to other pediocin-like bacteriocins, however, MIC determined for peptide treated with DTT were found to be significantly lower than the native peptide (Figure 5b). Again, M. luteus, L. monocytogenes and V. cholera were observed as the most sensitive, however, test strains like B. subtilis and E. coli were inhibited more efficiently with the DTT treated peptide compared to native peptide. Hemolysis of rabbit RBCs was not observed at concentrations up to $100 \mu \mathrm{M}$ of peptide.

\section{Conclusions}

Although production of LMW antimicrobial peptides from different bacteria was reported in the literature, no peptide of less than $2.5 \mathrm{kDa}$ was reported from Pediococcus species. Pediocin-like bacteriocins are produced by the pediocin biosynthetic gene cluster pedABCD that are highly conserved among Pediococcus strains, however, strains like $P$. acidilactici did not produce any antimicrobial substance though it contained pediocin biosynthetic 


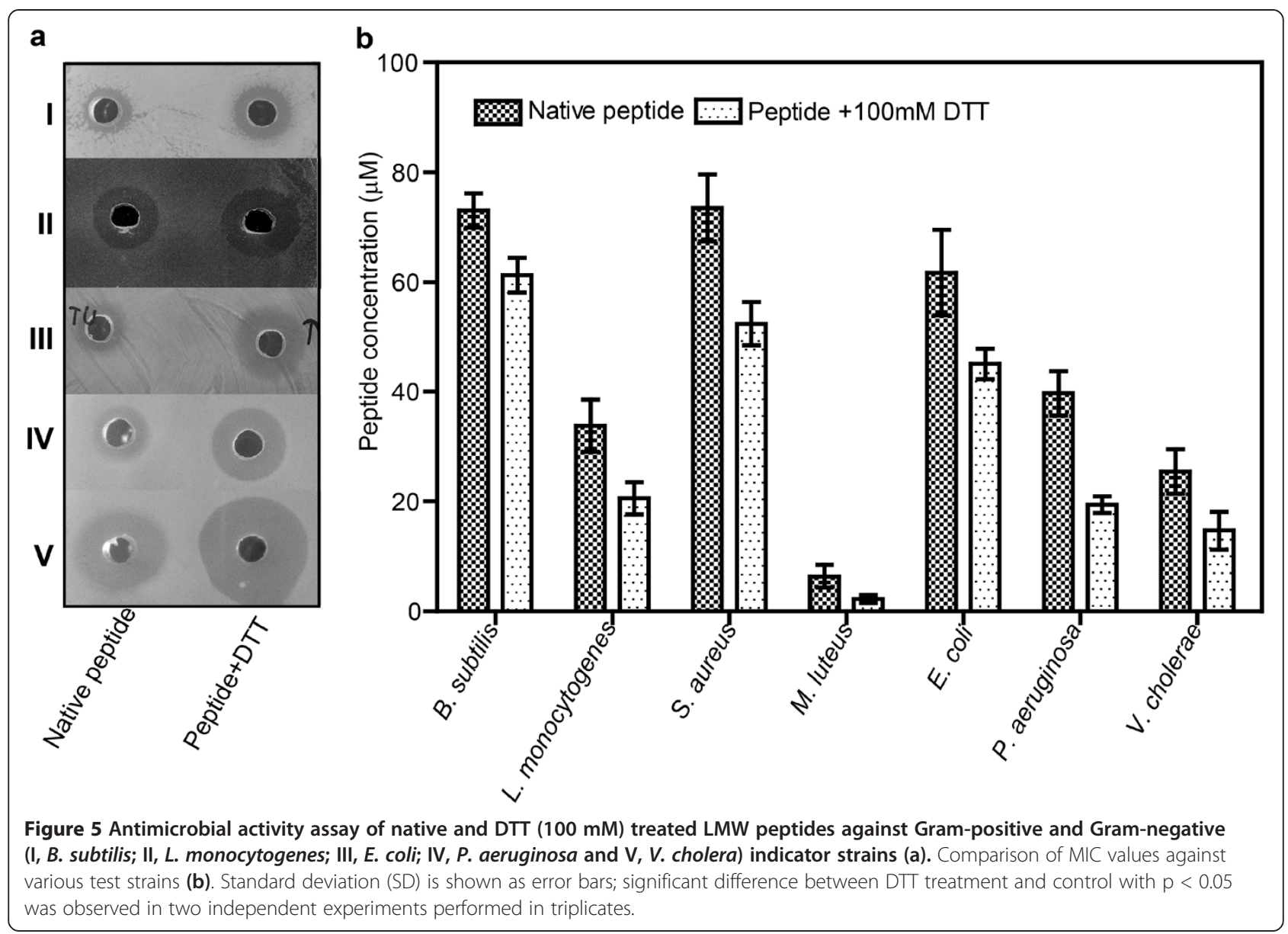

gene cluster. Similarly, the draft genome sequence of strain IE-3 in this study showed presence of pediocin biosynthetic gene cluster pedABCD but did not produce any pediocin-like bacteriocin. We conclude that $P$. pentosaceus strain IE-3 produces a LMW antimicrobial peptide with broad spectrum antimicrobial activity that is resistant to proteases. Therefore, it may be used effectively against food spoilage bacteria and developed as an efficient preservative for processed foods in food industry.

\section{Methods}

\section{Bacterial strains and growth media}

The antimicrobial producing bacterial strain IE-3 was isolated from a dairy industry effluent sample. The draft genome sequence of strain IE-3 has been published earlier [21]. All test strains used in the present study were obtained from Microbial Type Culture Collection and Gene Bank (MTCC and Gene Bank), CSIR-Institute of Microbial Technology, Chandigarh, India. Indicator strains like, Bacillus subtilis MTCC 121, Staphylococcus aureus MTCC 1430, Micrococcus luteus MTCC 106 Pseudomonas aeruginosa MTCC 1934, and Escherichia coli MTCC 1610 were grown on nutrient agar (M001, Himedia, India),
Vibrio cholerae MTCC 3904 was on LB medium (M1151, Himedia, India). Brain heart infusion agar (M1611, Himedia, India) was used to cultivate Listeria monocytogenes MTCC 839 and MRS medium (M641, Himedia, India) for Lactobacillus plantarum MTCC 2621. Clostridium bifermentans MTCC 11273, C. sordelli MTCC 11072, Pediococcus acidilactici MTCC 7442, P. pentosaceus MTCC 3817 and $P$. pentosaceus MTCC 9484 were grown on anaerobic agar (M228, Himedia, India). Among the eukaryotic test strains while Candida albicans MTCC 1637 was grown on YEPD medium (G038, Himedia, India), Czapek yeast extract agar (M1335, Himedia, India) was used to cultivate Aspergillus flavus MTCC8188. To test the influence of growth medium on antimicrobial production strain IE-3 was grown on nutrient broth (M002, Himedia, India), tryptone soya broth (LQ508, Himedia, India), reinforced clostridial broth (M443, Himedia, India), MRS broth (M369, Himedia, India) and minimal medium. Composition of anaerobic broth used for bacteriocin production contains (per liter) casein enzymic hydrolysate, 20.0 g; dextrose, 10.0 g; sodium chloride, 5.0 g; sodium thioglycollate, $2.0 \mathrm{~g}$; sodium formaldehyde sulphoxylate $1.0 \mathrm{~g}$; methylene blue, $0.002 \mathrm{~g}$ and $\mathrm{pH}$ adjusted to $7.2 \pm 0.2$. The minimal 
medium composed of (per liter) $\mathrm{K}_{2} \mathrm{HPO}_{4}, 0.5 \mathrm{~g}$; $\left(\mathrm{NH}_{4}\right)$ ${ }_{2} \mathrm{SO}_{4}, 0.5$ g; $\mathrm{MgSO}_{4} .7 \mathrm{H}_{2} \mathrm{O}, 0.1$ g; $\mathrm{FeSO}_{4} .7 \mathrm{H}_{2} \mathrm{O}, 0.02$ g; trace element solution $1 \mathrm{ml} ; \mathrm{NaNO}_{3}, 0.45 \mathrm{mg}$; L-Cysteine $\mathrm{HCl}, 50 \mathrm{mg}$ supplemented with $1 \%$ of dextrose or $0.05 \%$ of peptone or yeast extract. The dextrose solution was sterilized separately and added to the minimal medium after autoclave under aseptic conditions. All above media were prepared anaerobically (by purging with oxygen free nitrogen while boiling the medium) in serum vials and sealed under anaerobic conditions. Inoculation and sampling was done by using sterile syringes.

\section{Bacteriocin activity assay}

For antimicrobial peptide production strain IE-3 was grown in anaerobic broth for $48 \mathrm{~h}$ under anaerobic conditions using nitrogen gas. The culture was incubated at $30^{\circ} \mathrm{C}$ with shaking at $120 \mathrm{rpm}$ for optimal growth. The CFB obtained by removing the cells present in the medium by centrifugation $\left(6,000 \mathrm{~g}\right.$ for $\left.10 \mathrm{~min}, 4^{\circ} \mathrm{C}\right)$ and subsequent filtration of the supernatant through $0.22 \mu \mathrm{m}$ filter (Millipore, USA). The CFB was used to test the growth inhibition activity by agar well diffusion assay using actively growing test strains (between 0.2-0.4 OD). A growth curve verses antimicrobial production graph up to $48 \mathrm{~h}$ was constructed for strain IE-3 to examine the bacteriocin production at regular time intervals using anaerobic broth. Bacterial growth was measured as absorbance at $600 \mathrm{~nm}$ after constant time intervals of $2 \mathrm{~h}$ and antimicrobial activity at same time point was estimated by zone inhibition assay against $L$. monocytogenes test strain.

\section{Purification of low molecular weight antimicrobial peptide}

Strain IE-3 was grown anaerobically in serum vials at $30^{\circ} \mathrm{C}$ for $48 \mathrm{~h}$ for the maximum production of a LMW peptide. Antimicrobial compound was extracted from CFB using $2 \%$ activated Diaion HP20 (Sigma, USA) hydrophobic resin. The crude extract obtained was further purified through cation exchange (Capto S, GE Healthcare, USA) chromatography column linked to an AKTA prime plus (GE healthcare, USA), in $20 \mathrm{mM}$ sodium acetate buffer (pH 4.6) and eluted with $\mathrm{NaCl}$ gradient (50 to $1000 \mathrm{mM}$ ) in binding buffer. The peptide was desalted using dialysis tube (molecular cutoff $0.5 \mathrm{kDa}$, Spectrum, USA). Approximate molecular mass of peptide was determined by gel filtration column (Sodex KW-802.5) using standard molecular weight markers as described earlier [31]. Purity was confirmed by reversed phase HPLC $(10 \mathrm{~mm} \times 250 \mathrm{~mm} \times 150 \AA) \mathrm{C}-18$ column (venusil, Agela Technologies) under isocratic flow $(1.5 \mathrm{ml} / \mathrm{min})$ of acetonitrile (20\%) along with $0.1 \%$ TFA. Elution was monitored at $200-340 \mathrm{~nm}$ wavelength range on PDA detector and peaks were collected by fraction collector (1260 Infinity, Agilent technology, USA).

\section{In-gel activity assay}

The partially purified antimicrobial peptide (50 $\mu \mathrm{g} / \mathrm{lane})$ was electrophoresed in duplicate on $18.0 \%$ tricine SDSPAGE [32]. One set of the gel lane along with protein ladder (multi-color low range protein ladder, Thermo Spectra $^{\mathrm{Tx}}$ ) was stained with Coomassie brilliant blue to confirm the location of the antimicrobial peptide and the other lane of the gel was used to test antimicrobial activity as described earlier [33] by overlaying with $5 \mathrm{ml}$ of log-phase culture of L. monocytogenes $\left(10^{6}\right.$ cells $\left./ \mathrm{ml}\right)$ and was incubated at $30^{\circ} \mathrm{C}$ overnight.

\section{Intact mass analysis and de novo sequencing}

To analyze the molecular mass of peptide, purified peptide was electrophoresed, eluted from tricine SDS-PAGE by $75 \%$ acetonitrile with $0.1 \%$ TFA and used only for mass analysis and sequencing. Eluted peptide was mixed with equal ratios (1:1) of $\alpha$-cyano-4-hydroxycinnamic acid in $50 \%$ acetonitrile and $0.1 \%(\mathrm{v} / \mathrm{v})$ TFA. Samples were air dried and analyzed on an AB Sciex 5800 MALDI-TOF-TOF ${ }^{\mathrm{m}}$ mass spectrometer. MS/MS data was acquired at $1000 \mathrm{~Hz}$ in $1 \mathrm{kV}$ MSMS mode with 2000 laser shots/spectrum in CID (collision induced dissociation) mode to obtain maximum resolution. Sequence was generated by de novo explorer of $\mathrm{AB}$ Sciex and the highest score value sequence was considered as putative sequence. Further, structure was predicted on PEP-FOLD [34] server using de novo sequence. The structure obtained was visualized in PyMOL [35].

Determination of minimum inhibitory concentration (MIC) The MIC was determined for various indicator strains using a microtiter plate dilution assay as described earlier [31]. Cell growth was measured by observing OD at $600 \mathrm{~nm}$ at $16 \mathrm{~h}$ time interval using microtiter plate reader (Multiskan spectrum, Thermo, USA). The protein concentration was determined by BCA protein concentration estimation kit (Thermo, USA) following instructions of the manufacturer. For MIC determination of DTT treated peptide, the DTT solution was filter sterilized and final $100 \mathrm{mM}$ concentration was used to treat peptide.

\section{Effect of $\mathrm{pH}$, temperature, proteolytic enzymes, DTT and $\mathrm{H}_{2} \mathrm{O}_{2}$ on bacteriocin activity}

The sensitivity of the bacteriocin towards different $\mathrm{pH}$, temperatures and proteases was evaluated using purified bacteriocin. The purified peptide was incubated between $\mathrm{pH}$ values $2.0-10.0$ and temperatures including $80,100^{\circ} \mathrm{C}$ for $30 \mathrm{~min}$ and $120^{\circ} \mathrm{C}$ for $15 \mathrm{~min}$. Antimicrobial peptide $(200 \mu \mathrm{g})$ was incubated with various proteolytic enzymes such as trypsin $(10 \mu \mathrm{g} / \mathrm{ml}$, Sigma, USA), chymotrypsin (5 $\mathrm{\mu g} / \mathrm{ml}$, Sigma, USA) and proteinase K (5 units, Sigma, USA) in $100 \mathrm{mM}$ Tris $\mathrm{HCl}$ buffer $\mathrm{pH} 8.0$ (with $10 \mathrm{mM}$ 
$\left.\mathrm{CaCl}_{2}\right)$ at $30^{\circ} \mathrm{C}$ for $6 \mathrm{~h}$ to determine their effect. The enzyme activity was terminated by heating the reaction mix at $80^{\circ} \mathrm{C}$ and subsequently used for antimicrobial activity assay. To test the effect of denaturant like DTT (BioRad, USA) on antimicrobial activity of the peptide, it was incubated with 50 to $150 \mathrm{mM}$ DTT at room temperature for $1 \mathrm{~h}$ and used for growth inhibition assay. Hydrogen peroxide induced oxidation was tested by incubating the purified peptide with $100 \mathrm{mM}$ concentration of hydrogen peroxide (Merck, India) for $1 \mathrm{~h}$ at room temperature [36] and activity was tested by well diffusion assay.

\section{Hemolysis assay}

Blood was collected from New Zealand white rabbit, housed under normal conditions and had free access to a standard diet and water in Animal facility of the Institute. All animal protocols were followed according to the National Regulatory Guidelines issued by Committee for the Purpose of Control and Supervision of Experiments on Animals (CPCSEA), Ministry of Environment \& Forests (Government of India). Red blood cells (RBCs) were separated from the whole blood by centrifugation $(900 \mathrm{~g})$ and washed twice with phosphate buffer saline (PBS). Washed cells resuspended into PBS and were counted using heamocytometer. For heamolysis, $2 \times 10^{8}$ cells $/ \mathrm{ml}$ were used as mentioned [37]. They were treated with different concentrations of purified peptide (ranging from 5 to $100 \mu \mathrm{M}$ ) and incubated in $\mathrm{CO}_{2}$ incubator for $24 \mathrm{~h}$ at $37^{\circ} \mathrm{C}$. After incubation, cell free supernatant was separated by centrifugation (900 g) and absorbance was taken at $541 \mathrm{~nm}$. PBS and triton X100 $(0.1 \% \mathrm{v} / \mathrm{v})$ were used as baseline and $100 \%$ lysis controls, respectively.

\section{Statistical analysis}

Statistical significance of experimental results was determined by Student's $t$ test analysis and values of $\mathrm{p}<0.05$ were considered statistically significant. Data obtained from two individual experiments performed in triplicates was used.

\section{Competing interests}

Authors declare that they have no competing interest.

\section{Authors' contributions \\ PKS isolated the strain. PKS and SK participated in design of the experiments. PKS, SS and AK involved in identification and biochemical characterization of the strain and characterization of antimicrobial peptide, antimicrobial activity. PKS and SK analyzed the data. SK involved in coordination of experiments and writing the manuscript. All authors read the manuscript and approved the same.}

\section{Acknowledgements}

We thank Council of Scientific and Industrial Research (CSIR) and Department of Biotechnology, Government of India, for financial assistance. We would like to thank Dr. Prabhu B. Patil for useful discussion on genomic data analysis and Mrs. Sharanjeet Kaur for her help in MALDI-TOF analysis of peptide.
Received: 14 March 2014 Accepted: 18 August 2014

Published: 27 August 2014

\section{References}

1. Klaenhammer TR: Genetics of bacteriocins produced by lactic acid bacteria. FEMS Microbiol Rev 1993, 12(1):39-85.

2. Van Belkum MJ, Stiles ME: Nonlantibiotic antibacterial peptides from lactic acid bacteria. Nat Prod Rep 2000, 17(4):323-335.

3. Guinane C, Cotter P, Hill C, Ross R: Microbial solutions to microbial problems; lactococcal bacteriocins for the control of undesirable biota in food. J Appl Microbiol 2005, 98(6):1316-1325.

4. Cotter PD, Ross RP, Hill C: Bacteriocins-a viable alternative to antibiotics? Nat Rev Microbiol 2013, 11(2):95-105.

5. Eijsink VG, Skeie M, Middelhoven PH, Brurberg MB, Nes IF: Comparative studies of class lla bacteriocins of lactic acid bacteria. Appl Environ Microbiol 1998, 64(9):3275-3281.

6. Pucci MJ, Vedamuthu ER, Kunka BS, Vandenbergh PA: Inhibition of Listeria monocytogenes by using bacteriocin PA-1 produced by Pediococcus acidilactici PAC 1.0. Appl Environ Microbiol 1988, 54(10):2349-2353.

7. Bhunia A, Johnson M, Ray B: Purification, characterization and antimicrobial spectrum of a bacteriocin produced by Pediococcus acidilactici. J App/ Microbiol 1988, 65(4):261-268.

8. Green G, Dicks L, Bruggeman G, Vandamme E, Chikindas M: Pediocin PD-1, a bactericidal antimicrobial peptide from Pediococcus damnosus NCFB 1832. J Appl Microbiol 1997, 83(1):127-132.

9. Henderson JT, Chopko AL, Van Wassenaar PD: Purification and primary structure of pediocin PA-1 produced by Pediococcus acidilactici PAC-1.0. Arch Biochem Biophys 1992, 295(1):5-12.

10. Rodriguez JM, Martinez MI, Kok J: Pediocin PA-1, a wide-spectrum bacteriocin from lactic acid bacteria. Crit Rev Food Sci Nutr 2002, 42(2):91-121.

11. Papagianni M, Anastasiadou S: Pediocins: the bacteriocins of Pediococci: sources, production, properties and applications. Microb Cell Factories 2009, 8(1):3.

12. Aymerich T, Holo H, Håvarstein LS, Hugas M, Garriga M, Nes IF: Biochemical and genetic characterization of enterocin A from Enterococcus faecium, a new antilisterial bacteriocin in the pediocin family of bacteriocins. Appl Environ Microbiol 1996, 62(5):1676-1682.

13. Ennahar $S$, Aoude-Werner D, Sorokine O, Van Dorsselaer A, Bringel F Hubert J-C, Hasselmann C: Production of pediocin AcH by Lactobacillus plantarum WHE 92 isolated from cheese. Appl Environ Microbiol 1996, 62(12):4381-4387.

14. Le Marrec C, Hyronimus B, Bressollier P, Verneuil B, Urdaci MC: Biochemical and genetic characterization of coagulin, a new antilisterial bacteriocin in the pediocin family of bacteriocins, produced by Bacillus coagulans 14 . Appl Environ Microbiol 2000, 66(12):5213-5220.

15. Millette M, Dupont C, Archambault D, Lacroix M: Partial characterization of bacteriocins produced by human Lactococcus lactis and Pediococccus acidilactici isolates. J Appl Microbiol 2007, 102(1):274-282.

16. Millette M, Dupont C, Shareck F, Ruiz M, Archambault D, Lacroix M: Purification and identification of the pediocin produced by Pediococcus acidilactici MM33, a new human intestinal strain. J Appl Microbiol 2008 104(1):269-275.

17. Ray B, Miller KW: Natural food antimicrobial systems". In Pediocins of Pediococcus species. Edited by Naidu AS. Boca Raton, FL: CRC Press; 2000:525-566.

18. Fimland G, Jack R, Jung G, Nes IF, Nissen-Meyer J: The bactericidal activity of pediocin PA-1 is specifically inhibited by a 15 -mer fragment that spans the bacteriocin from the center toward the $\mathrm{C}$ terminus. Appl Environ Microbiol 1998, 64(12):5057-5060.

19. Chen Y, Shapira R, Eisenstein M, Montville TJ: Functional characterization of pediocin PA-1 binding to liposomes in the absence of a protein receptor and its relationship to a predicted tertiary structure. Appl Environ Microbiol 1997, 63(2):524-531.

20. Chen Y, Ludescher RD, Montville TJ: Electrostatic interactions, but not the YGNGV consensus motif, govern the binding of pediocin PA-1 and its fragments to phospholipid vesicles. Appl Environ Microbiol 1997, 63(12):4770-4777.

21. Midha S, Ranjan M, Sharma V, Kumari A, Singh PK, Korpole S, Patil PB: Genome sequence of Pediococcus pentosaceus Strain IE-3. J Bacterio 2012, 194(16):4468-4468 
22. Johnsen L, Fimland G, Eijsink V, Nissen-Meyer J: Engineering increased stability in the antimicrobial peptide pediocin PA-1. Appl Environ Microbiol 2000, 66(11):4798-4802.

23. Hammami R, Zouhir A, Hamida JB, Fliss I: BACTIBASE: a new webaccessible database for bacteriocin characterization. BMC Microbiol 2007, 7(1):89.

24. Hammami R, Zouhir A, Le Lay C, Hamida JB, Fliss I: BACTIBASE second release: a database and tool platform for bacteriocin characterization. BMC Microbiol 2010, 10(1):22.

25. Thomas S, Karnik S, Barai RS, Jayaraman VK, Idicula-Thomas S: CAMP: a useful resource for research on antimicrobial peptides. Nucleic Acids Res 2010, 38(suppl 1):D774-D780.

26. Wang G, Li X, Wang Z: APD2: the updated antimicrobial peptide database and its application in peptide design. Nucleic Acids Res 2009, 37(suppl 1):D933-D937.

27. Simmaco M, Mignogna G, Canofeni S, Miele R, Mangoni ML, Barra D: Temporins, antimicrobial peptides from the European red frog Rana temporaria. Eur J Biochem 1996, 242(3):788-792.

28. Fimland G, Johnsen L, Dalhus B, Nissen-Meyer J: Pediocin-like antimicrobial peptides (class lla bacteriocins) and their immunity proteins: biosynthesis, structure, and mode of action. J Pept Sci 2005, 11(11):688-696.

29. Hastings J, Sailer M, Johnson K, Roy K, Vederas J, Stiles M: Characterization of leucocin A-UAL 187 and cloning of the bacteriocin gene from Leuconostoc gelidum. J Bacteriol 1991, 173(23):7491-7500.

30. Song D, Li X, Zhang Y, Zhu M, Gu Q: Mutational analysis of positively charged residues in the $\mathrm{N}$-terminal region of the class lla bacteriocin pediocin PA-1. Lett Appl Microbiol 2014, 58(4):356-361.

31. Singh PK, Chittpurna, Ashish, Sharma V, Patil PB, Korpole S: Identification purification and characterization of laterosporulin, a novel bacteriocin produced by Brevibacillus sp. Strain GI-9. PLoS One 2012, 7(3):e31498.

32. Schägger H: Tricine-sds-page. Nat Protoc 2006, 1(1):16-22.

33. Baindara P, Mandal SM, Chawla N, Singh PK, Pinnaka AK, Korpole S: Characterization of two antimicrobial peptides produced by a halotolerant Bacillus subtilis strain SK. DU. 4 isolated from a rhizosphere soil sample. AMB Express 2013, 3(1):1-11.

34. Maupetit J, Derreumaux P, Tuffery P: PEP-FOLD: an online resource for de novo peptide structure prediction. Nucleic Acids Res 2009, 37(suppl 2):W498-W503.

35. DeLano WL: PyMOL. San Carlos CA: DeLano Scientific; 2002:700.

36. Van Patten SM, Hanson E, Bernasconi R, Zhang K, Manavalan P, Cole ES, McPherson JM, Edmunds T: Oxidation of methionine residues in antithrombin effects on biological activity and heparin binding. J Biol Chem 1999, 274(15):10268-10276.

37. Ghosh JK, Shaool D, Guillaud P, Cicéron L, Mazier D, Kustanovich I, Shai Y, Mor A: Selective cytotoxicity of dermaseptin S3 toward intraerythrocytic Plasmodium falciparum and the underlying molecular basis. J Biol Chem 1997, 272(50):31609-31616.

doi:10.1186/s12866-014-0226-2

Cite this article as: Singh et al:: A non-pediocin low molecular weight antimicrobial peptide produced by Pediococcus pentosaceus strain IE-3 shows increased activity under reducing environment. BMC Microbiology

2014 14:226.

\section{Submit your next manuscript to BioMed Central and take full advantage of:}

- Convenient online submission

- Thorough peer review

- No space constraints or color figure charges

- Immediate publication on acceptance

- Inclusion in PubMed, CAS, Scopus and Google Scholar

- Research which is freely available for redistribution 